\title{
Components of metacognition and metacognitive properties of forecasting as determinants of supra-situational pedagogical thinking
}

\author{
Mergalyas M. Kashapov $^{a}$, Irina V. Serafimovich ${ }^{b}$, Yulia V. Poshekhonova ${ }^{a}$ \\ a Department of Pedagogics and Pedagogical Psychology, Demidov State University, Yaroslavl, \\ Russia \\ ${ }^{\mathrm{b}}$ Department of Humanities, Yaroslavl Branch of Plekhanov Russian University of Economics, \\ Yaroslavl, Russia \\ *Corresponding author. E-mail: iserafimovich@yandex.ru
}

This article describes the functions of metacognition and the role of these functions in professional pedagogical thinking (PPT): the discovery of the emergence of a problemacy, the organization of cognition processes, and the management of the comprehension and resolution of the problem situation. Thinking is related to the metacognitive activity of a subject. Components and strategies of metacognition are included in the PPT process and define (by means of conscious or unconscious regulation) the efficiency of discovering and solving problems in an interpersonal interaction situation that must be comprehended and transformed. One of the conditions providing for realization of the supra-situational thinking of professionals is a high level of metacognitive activity, although the level of the pronouncedness of metacognitive activity does not depend on the subject's possessing basic professional education.

We have created and tested new psychodiagnostic techniques aimed at defining the level of forecasting in problem (conflict) situations and at evaluating metacognitive knowledge and activity. The sample group included about 800 people (university lecturers, school teachers, and teachers who train college students). It was proved that the metacognitive focus of forecasting stimulates the formation and development of various forecasting types: proactive, retroactive, and interactive. Forecasting is viewed as a metacognitive component of supra-situational thinking and a component of the cognitive side of communication. Situational and supra-situational types of pedagogical thinking are shown to have different properties and different orientations toward forecasting activity; these properties and orientations determine the differentiation and hierarchization of these types of thinking. It was discovered that the metacognitive properties of supra-situational thinking are achieved through a high degree of integration of all basic forecasting qualities (analyticity, depth, awareness, flexibility, prospectiveness, and validity).

The efficiency of our devised and tested program aimed at perfecting PPT is evident in the dynamics of its objective and subjective properties (an increased level of supra- 
situativity of thinking among the program participants and the participants' subjective evaluations of transformation in coping with difficulties in conflict situations). The formation of supra-situational thinking-in particular, of components such as forecasting (in both a narrow and a broad context) - is closely connected with envisaging prospects, including those for one's own professional and personality development.

Keywords: metacognition, metacognitive knowledge, metacognitive activity, forecasting, supra-situativity of professional thinking

\section{Introduction}

At the present stage of social development it is vital to meet challenges in a flexible and timely way in the education field because modern education is not only and not so much related to giving knowledge but rather is aimed at personality and metasubject results. In view of this goal, the issue of teachers' professional training and retraining and of the formation of PPT, which is a crucial factor in the organization and orientation of professional behavior and communication, is becoming urgent. Accordingly, meeting new educational requirements that strengthen efficiency in mastering all professional spheres, that increase the competitiveness of professionals in different fields, and that help in solving many other constantly changing social problems is possible only within the framework of pedagogical activities. Therefore, researching PPT and its metacognitive conditionality is crucial and fundamental not only for cognitive psychology but also for social psychology. Here we see a possible solution to the above-mentioned problems of enabling the formation of supra-situational thinking through transforming one of its components, forecasting, which has a metacognitive nature, and of perfecting metacognitive components (metacognitive knowledge and metacognitive activity).

PPT satisfies all general laws regarding thinking, although, in accordance with professional-thinking theory, it has its own peculiarities (Gonobolin, 1951; Karpov \& Skityayeva, 2005; Kashapov, 2000; Kulyutkin, 1986; Kuzmina, 1961; Markova, 1993; Mazilov, 1998; Mitina, 1998; Osipova, 1987; Povaryonkov, 1998; Sukhobskaya, 1975). Kashapov (2000) has suggested treating PPT as a cognitive process of discovering and solving pedagogical problems with the personal involvement of teachers in transformations in the course of their pedagogical activities. Brushlinsky (1977), Kudryavtsev (1997), Matyushkin (1972), Putlyaeva (1986), and Rubinstein (2000) suggest viewing problemacy as an elementary unit of PPT.

Psychological analysis of PPT and metacognitive personality structures shows their close interconnection. The subjects of activity not only comprehend their own cognitive processes but willingly watch them (Flavell, 2002), in which case metacognitive processes are intentional, planned, purposeful, and oriented toward future mental behavior, which can be used for solving cognitive tasks.

Analysis of Russian and foreign research materials leads to the conclusion that subjects of activity can be differentiated according to the level of their metacognitive abilities; those with more pronounced metacognitive abilities are more successful, and metacognition itself appears to be related to other factors that define activity efficiency. The results of research by Pintrich and DeGroot (1990) point to a positive connection among motivation, the broad use of metacognitive strategies 
(the authors include here connections between new and old information, purposeful selection of thinking strategies, planning, and control and evaluation of thinking processes), and critical thinking. Clause, Delbridge, Schmitt, Chan, \& Jennings (2001) found that motivation is related to metacognition and learning strategies and eventually to higher test performance.

Metacognition (as contemplation about one's own thoughts) is related to the need for cognition (Tormala, \& DeSensi, 2008, Petty, Briñol, \& Barden, 2007; Petty, Tormala, \& Rucker, 2004), flexibility in changing attitudes, and confidence in one's own opinion (Barden \& Petty, 2007). Having analyzed various foreign research dedicated to the need for cognition, Shebetenko (2011) worked out a Russian version of the Need for Cognition Scale (Cacioppo, Petty, \& Kao, 1984); need for cognition is viewed as an aspect of openness to new experience and as individual differences in cognitive motivation to be involved in and enjoy complex cognitive tasks.

Many research works are dedicated to studying the dependence of properties of metacognition on respondents' ages. Thus, a group of scientists (Sperling, Howard, Miller, \& Murphy, 2002), while studying the metacognitive knowledge and self-regulation of junior school students, discovered that metacognitions were developed quicker among the junior than among the senior students; according to the authors, such development requires extra analysis and research. The latest foreign research (Whitebread, 2014) gives convincing proof that early development of metacognition, as a basis for self-regulation, is possible, especially in the rather practical spheres of children's life activities: skills in discussing interactions in problem situations and skills in behaving safely in everyday life and on the street. These data correlate with the point of view of Russian author T. Ye. Chernokova (2011), who supposed that the prerequisites for metacognition are formed during the preschool years. The author includes in the structure of metacognitive processes goal setting, conditions' modeling, programming, and action control aimed at reaching the set cognition goals.

Metacognition research can be diverse. Thus, Prytula (2012) admits the possibility of studying the properties of metacognition in leading teachers, as well as tutoring and support for young teachers using metacognition resources. Gigerenzer \& Gaissmaier (2011) confirm the great role of metacognitive processes in decision-making and the importance of heuristics for finding an optimal solution in situations of uncertainty (using doctors, managers, and lawyers as examples). Kramarski studies metacognitions (as self-regulation) by taking as an example the use of thinking processes in mathematics and for doing math problems; in his latest research he adds an important component of metacognition study in the modern world-using metacognitive processes in electronic learning and work with computers (Kramarski, 2008).

Metacognition is related to reflection, one of the basic mechanisms regulating a subject's thinking activity (Karpov \& Skityayeva, 2005) to intellect (Borkowski \& Muthukrishna, 1992; Kholodnaya, 2002; Sternberg, 1998) and to existential experience (Znakov, 2012). As a working definition of metacognition, Poshekhonova (2012) has suggested the following: metacognition is knowledge of your own thinking processes and strategies, ability to intentional reflection on these processes and strategies, and changing and performing actions based on this knowledge. 
Various researchers stress that any subject's activity aimed at planning to resolve a problem situation, controlling comprehension of the situation, and evaluating progress in resolving the situation is metacognitive by itself. This statement allows us to state that forecasting, as thinking activity, is metacognitive. Regush (1985), viewing forecasting as an activity (unity of content, operational and motivational components) and an ability, pointed out, first, the conditions necessary for forecasting ability to develop (knowledge, motives, intentional formation of the operational side of forecasting) and, second, the structure of forecasting, including such qualities as analyticity, depth, deliberation, flexibility, prospectiveness, and validity; the specific (factorial) importance of these qualities is defined by their place in a given sequence. From our point of view, it makes sense to view forecasting not only as ability but also as metacognition because it promotes the realization of supra-situational thinking. In the works of Kashapov the notion of "suprasituational thinking" was introduced and its basic content was explained (2000, p. 281). In the context of this research, supra-situational thinking is viewed as the "thinking process including forecasting the progress, results, and consequences of resolving conflict situations and, depending on the completeness of the forecasting metacognition structure, providing this or that level of professional thinking" (Serafimovich, 2002, p. 75).

Of late not only has there been growing interest in the notion of metacognitions but also there have been attempts to sort out the terminology and to make constructs increasingly precise. Besides, there is a paradoxical tendency: Russian researchers try to discover and understand foreign scientists' notions of metacognition (Kornilova, 2009; Litvinov \& Ivolina, 2014; Shebetenko, 2011), while foreign researchers, like Fox and Riconscente (2008), turn to primary sources of metacognitive abilities in Russian psychology. Here we agree with the point of view of Kornilova (2009) that looking to foreign sources sometimes leads to simplification and not quite correct interpretations of certain notions and terms, their essence and profound meaning. We would like for this article to become yet another step toward mutual understanding between Russian and foreign scientists through its revelation of new facets of metacognition as realized in suprasituational PPT.

The objective of this work is to explore metacognitive components of PPT and metacognitive characteristics of forecasting as determinants of supra-situational thinking. The research was carried out in teachers' training courses at colleges and universities and during their professional retraining in brush-up courses. For diagnosing the research findings, original techniques were worked out and verified psychometrically. This procedure helped us estimate the connection between PPT levels and forecasting and metacognition components (metacognitive knowledge and metacognitive activity). The research was conducted between 2006 and 2014, with about 800 subjects involved.

\section{First stage of the research}

The goal was to study metacognitive characteristics of forecasting as determinants of suprasituational thinking. 


\section{Method}

The comparative and cross-sectional methods (organizational methods) used included: observations, questionnaires, interviews, talks; expert evaluations of school students, colleagues, and specialists; sociometry with forecasting; the Questionnaire for Defining the Dominating Level of the Problemacy in Resolving Pedagogical Problem Situations (Yu. N. Dubrovina and M. M. Kashapov); and Diagnostics of the Situational/Supra-Situational Level of Pedagogical Thinking (T. G. Kiselyova and M. M. Kashapov). The methods that mediately showed the level of forecasting development were: R. B. Cattell's 16PF Personality Test; the Wechsler Adult Intelligence Scale (WAIS); the Way Out of Difficult Life Situations and Pedagogical Abilities tests of R. S. Nemov; the method of diagnosing the level of subjective control by J. B. Rotter, adapted by Ye. F. Bazhin, S. A. Golynkina, and A. M. Etkind; the Questionnaire for Defining the Style of Pedagogical Activity (A. K. Markova and A. Ya. Nikonova).

We also worked out and tested the Method for Defining the Level of Forecasting in Problem (Conflict) Situations (I. V. Serafimovich and M. M. Kashapov), in which while solving problem situations one needs to provide, apart from personal decisions, argumentation and substantiation of the choice of each variant of the answer and one needs also to forecast one's own behavior in view of several types of prospects (forecasting the process and effects in the near future) and forecasting consequences (forecasting the distant future). The sample group included 230 educators (secondary, vocational, and technical school teachers) and 200 university students (2nd-, 3rd-, and 4th-year students of pedagogics and a group of nonpedagogics students).

\section{Results}

Our work included a modification of 10 problem situations teachers most often run into (as devised by T. G. Kiselyova and M. M. Kashapov), with the choice of situation solution being open, to be substantiated according to three parameters: the subject's action and how the situation could develop, possible results, possible consequences. In our opinion, argumentation and substantiation of each option change the evaluation of the PPT itself dramatically. Because some of the answers tend to be socially approved, there may be a certain dissonance between the behavior chosen in the test situation and the behavior in a similar real-life situation. In a modification proposed by T. G. Kiselyova, this dissonance is minimized through moving the focus to the evaluation of someone else's behavior. We combine the choice of behavior with the substantiation, the verbal statement predicting various possible consequences of teachers' actions.

For example, here is a problem situation: "You are explaining some new material in class, and one of its aspects causes unexpected laughter. What are you going to do?" Different solutions can be offered with their substantiation and various levels of forecasting (analysis, depth, prospectiveness, validity, flexibility, and awareness). Low levels of forecasting give such solutions as: "They have to study it all; there is no time to laugh, and the class will go on as before." "I have to explain a new topic, so I will...; if they do not want to listen, it is their problem." "I know my subject so well that it cannot happen in my class." "I am going to interrupt my story and restore discipline somehow, and everything will be fine." High levels of 
forecasting presuppose other solution options: «Causing laughter is a natural and integral part of life. If there is a chance I shall find out everything in class, if not, then later.... We could laugh together if it is worth it; therefore the contact with my students will be good." "I am going to find out the reason. If I am to blame, I shall apologize. If there is no clear reason, we shall look for the solution together and maybe a discussion starts that develops creative thinking." "Laughter may be a sort of question from some children. If extra information is interesting to all, we shall prepare it for the next class. To some, I shall recommend extra reading. At the same time I will find the answer myself and later create a complex solution together with children."

During the approval of the method to define forecasting level in problem (conflict) situations (carried out by I. V. Serafimovich and M. M. Kashapov) the contents of test points were studied by means of content analysis (analyzing both quality and quantity). (The sample group included 85 school and college teachers.) The reliability of the test by homogeneity (inner concordance) was defined with the split half method. Because the obtained value of .745 was higher than the recommended .6, the test can be considered reliable. The degree of concordance of experts evaluating various levels of forecasting was tested by means of Cronbach's alpha.

Testing of the questionnaire was done according to several kinds of validity. Evaluating the criterial validity of the questionnaire was done using the contrastinggroup method. There were three groups of 2nd-, 3rd-, and 4th-year students of pedagogics and a group of lecturers of various subjects. The sample group on which validity was checked consisted of 120 people (30 per group). From the research, we got reliable differences $(p \leq .05)$ (Table 1$)$. This method proved that forecasting keeps developing in the process of learning and mastering pedagogical activities.

Table 1. Evaluating the credibility of differences in forecasting levels

\begin{tabular}{lcccc}
\hline $\begin{array}{c}\text { Sample groups } \\
\text { to compare }\end{array}$ & $\begin{array}{c}\text { 2nd- and 3rd- } \\
\text { year students }\end{array}$ & $\begin{array}{c}\text { 3rd- and 4th- } \\
\text { year students }\end{array}$ & $\begin{array}{c}\text { 4th-year } \\
\text { students and } \\
\text { teachers }\end{array}$ & $\begin{array}{c}\text { All together (2nd- } \\
\text { to 4th-year stu- } \\
\text { dents) and teachers }\end{array}$ \\
\hline $\begin{array}{l}\text { Value of } t \text {-criterion } \\
\text { for students }\end{array}$ & $1.864^{*}$ & $2.426^{*}$ & -1.232 & $-4.366^{* *}$ \\
\hline
\end{tabular}

Note. Importance of level of connection: ${ }^{* *}-.99,{ }^{*}-.95$

Checking the construct validity of the questionnaire was done by comparing the results obtained on level of forecasting and the results of certain methods (with the help of Spearman's rank correlation coefficient): (a) for defining the level of subjective control that reflects the degree of responsibility for various life aspects $(r=.425, p \leq .05)$; (b) for discovering ways out of difficult life situations (R. S. Nemov) $(r=.519, p \leq .05)$; (c) for finding the dominating level of the problemacy in resolving pedagogical problem situations (Yu. N. Dubrovina and M. M. Kashapov) $(r=.830, p \leq .01)$; (d) for detecting individual activity style (A. K. Markova and A. Ya. Nikonova): emotional-methodical and deliberating-improvising styles including forecasting of both immediate and future results of an activity $(r=.620, p \leq .05)$. The 
choice of methods for checking construct validity was based on the similarity of the constructs implied in the questionnaires; each construct reflects various aspects time perspective and content characteristics - of forecasting activity.

Checking the empirical validity of the questionnaire was done using exterior criteria of professional competence: peer review of administration $(r=.488, p \leq .05)$ and qualification category (second, first, higher) $(r=.643, p \leq .05)$. At the last stage of working out the questionnaire, approximate norms were presented (the sample group included 285 people: 85 lecturers and 200 students), and four levels of forecasting were defined: low, medium-low, medium-high, and high; these levels differed in both the number of forecasting qualities and the level of their usage.

In the course of research aimed at studying the connection and relationship between forecasting and situativity/supra-situativity, it was established that a low level of forecasting the progress, effects, and consequences of resolving problem situations determines various levels of situational and supra-situational thinking, while using different forecasting properties allows for increasing the supra-situativity of solutions.

Four levels of forecasting determine four levels of professional thinking. A low level of forecasting ( $0-4$ grades) is observed when most forecasting qualities are not represented; one quality may be highly developed with the others absent (while realizing situational or supra-situational levels without using forecasting). A medium-low level of forecasting (4-9 grades) is observed when from one to four forecasting qualities are represented, with the level of their development usually not balanced - that is, some are represented highly and others not at all (at a situational level of thinking with elements of forecasting). A medium-high level of forecasting (9-13 grades) is observed when at least three forecasting qualities are represented at high and medium-high levels and their level of development is balanced; at this level, supra-situational thinking is realized, although with inflexible forecasting. A high level of forecasting (9-13 grades) is observed when all the forecasting qualities are represented (depth, analyticity, purposefulness, potentiality, and validity); all conditions for using supra-situational thinking are represented with developed and dynamic forecasting.

In our research, we established that the supra-situational level of problem detection is related to supra-situational thinking, but at a qualitatively different level of forecasting as defined by the nature of the activity mastered (pedagogical specialization) and the stage of professionalization. While one is mastering different stages of professionalization, the quality of the supra-situational level is gradually increasing. In order to prove the hypothesis that levels of thinking gradually transform from situational into supra-situational in the process of acquiring pedagogical specialization, Pearson's $\chi^{2}$ test was used (Table 2 ). Statistically significant results $(p \leq .05)$ were obtained while comparing changes in the thinking levels of students in the 2 nd to 4 th years: situational without substantiation $\left(\chi^{2}=35.935\right)$, supra-situational without substantiation $\left(\chi^{2}=64.625\right)$, supra-situational without forecasting $\left(\chi^{2}=372.378\right)$, and situational with elements of forecasting $\left(\chi^{2}=44.342, p \leq .01\right)$; these results prove the gradual transformation of situational structural-level characteristics into supra-situational characteristics through acquisition of the theoretical knowledge necessary for forecasting and developing practical skills for using forecasting in the process of studies at a pedagogical college. 
Table 2. Comparing the supra-situational level of discovering pedagogical problems and forecasting quality

\begin{tabular}{|c|c|c|c|c|c|c|c|c|}
\hline \multicolumn{2}{|c|}{$\begin{array}{l}\text { Forecasting quality } \\
\text { (L. A. Regush }\end{array}$} & \multirow{2}{*}{$\begin{array}{l}\begin{array}{c}\text { Depth } \\
\text { (Dp) }\end{array} \\
-.484^{* *}\end{array}$} & \multirow{2}{*}{$\begin{array}{c}\begin{array}{c}\text { Analyti- } \\
\text { city (An) }\end{array} \\
-.457^{\star *}\end{array}$} & \multirow{2}{*}{$\begin{array}{c}\text { Awareness } \\
\text { (Aw) } \\
-.483^{* *}\end{array}$} & \multirow{2}{*}{$\begin{array}{l}\text { Flexibi- } \\
\text { lity (F) } \\
-.490^{\star *}\end{array}$} & \multirow{2}{*}{$\begin{array}{c}\text { Prospec- } \\
\text { tiveness } \\
(\mathrm{P})\end{array}$} & \multirow{2}{*}{$\begin{array}{c}\text { Validity } \\
(\mathrm{V}) \\
-.509^{\star *}\end{array}$} & \multirow{2}{*}{$\begin{array}{c}\begin{array}{c}\text { General } \\
\text { predictive } \\
\text { value }\end{array} \\
-.478^{\star *}\end{array}$} \\
\hline & Teachers & & & & & & & \\
\hline $\begin{array}{l}\text { profession- } \\
\text { alization }\end{array}$ & $\begin{array}{l}\text { Students of } \\
\text { pedagogics }\end{array}$ & $-.288^{\star *}$ & $-.235^{\star *}$ & $-.249^{* *}$ & & $-.175^{\star}$ & $-.289^{* *}$ & $-.289^{\star *}$ \\
\hline \multirow{3}{*}{$\begin{array}{l}\text { Stages of } \\
\text { pedagogic } \\
\text { professio- } \\
\text { nalization }\end{array}$} & 2nd year & $-.486^{* *}$ & $-.398^{\star}$ & $-.430^{*}$ & $-.454^{*}$ & -.255 & -.292 & $-.468^{\star}$ \\
\hline & 3 rd year & $-.247^{\star}$ & $-.239^{*}$ & -.188 & -.221 & -.168 & $-.280^{*}$ & $-.244^{\star}$ \\
\hline & 4 th year & -.368 & -.26 & -.335 & -.311 & -.254 & $-.512^{*}$ & $-.511^{\star}$ \\
\hline
\end{tabular}

Note. Importance of level of connection: ${ }^{*}-.99 ;^{*}-.95$

The forecasting of the nonpedagogical students was heterochronic and uneven at all levels of thinking with the use of forecasting (medical students were taken as an example). With the pedagogical students and the lecturers this influence was homogeneous; although the increased use of forecasting gradually elicited higher levels of thinking, this use decreased somewhat at the supra-situational level with high dynamic forecasting. We think that this result occurred not because forecasting was not used but because it had a more compressed nature.

\section{Second stage of the research}

The goal at this stage was to explore the metacognitive components of PPT.

\section{Method}

We worked out and tested the method Evaluation of Metacognitive Knowledge and Metacognitive Activity (Yu. V. Poshekhonova and M. M. Kashapov) in order to evaluate the pronouncedness of two metacognition components-metacognitive knowledge and metacognitive activity. The sample group included 163 teachers (among them 128 university lecturers and 35 secondary school teachers) and 237 university students.

In addition, the following methods were used: Diagnostics of the Situational/Supra-Situational Level of Pedagogical Thinking (T. G. Kiselyova and M. M. Kashapov) (this method includes 10 situations and allows for defining the degree of pronouncedness of the situational or supra-situational level of PPT); questionnaires of N. V. Klyueva for revealing teachers' abilities for self-development, as well as factors stimulating and preventing the learning, development, and self-development of teachers and lecturers; the method Need for Achievement of Yu. M. Orlov; and the Interpersonal Diagnosis of Personality of T. Leary, R. L. Leforge, and R. F. Sathek. The sample group included 59 university lecturers. 


\section{Results}

Working out the method of self-evaluation of metacognitive knowledge and metacognitive activity took place in three stages. In the first stage, we administered a preliminary questionnaire of 39 statements in order to define two scales: selfevaluation of metacognitive knowledge (MK) and metacognitive activity (MA). The MK scale rates one's evaluation of the general functioning level of one's own cognitive psychic processes (attention, memory, thinking) and degree of easiness in acquiring new knowledge (for example, "I can use at least several ways to learn the material"). The MA scale deals with components of metacognitive experience that provide for conscious regulation of one's own intellectual behavior: using various approaches to structuring information, planning one's own cognitive activity, managing one's own cognitive processes (for example, "I usually study the material quite well").

The second stage consisted of testing the questionnaire's scales for reliability (reliability of equivalent halves of the test and reliability as stability) and validity. In order to check the construct validity, we used methods for defining the development levels of volitional self-control: the test-questionnaire of A.V. Zverkov and E.V. Eidman and the method Need for Achievement by Yu.M. Orlov. The method for defining volitional self-control development levels included 30 statements and allowed for defining indices of volitional self-control according to general scale points, as well as indices according to the subscales "persistence" and "self-control"; correlations for the scales of the worked-out method, according to Spearman, were at $p \leq .02$. The method Need for Achievement contains one scale, level of achievement motivation, which is evaluated through 23 statements; there were no significant correlations with this scale.

For checking criterial validity, we used the criteria of academic performance, education, gender, and age. We specified the relationship between academic performance and metacognitive characteristics. Calculation of Spearman's rank correlation coefficient between academic performance and the MA scale showed a significant connection $(r=.297, p \leq .05)$; no significant correlation with the MK scale was discovered. This result reveals that students who use metacognitive strategies actively show better academic progress than those who use them less, and it proves the hypothesis that activity efficiency increases when metacognitive processes are included in it.

Table 3. Testing the reliability of the method Evaluation of Metacognitive Knowledge and Metacognitive Activity

\begin{tabular}{lcc}
\hline \multicolumn{1}{c}{ Criterion } & $\begin{array}{c}\text { Metacognitive knowledge } \\
\text { scale }\end{array}$ & $\begin{array}{c}\text { Metacognitive activity } \\
\text { scale }\end{array}$ \\
\hline Spearman-Brown $(n=95)$ & $.751^{* *}$ & $.631^{\star *}$ \\
$\begin{array}{l}\text { Pearson's correlation coefficient } \\
(n=65)\end{array}$ & $.398^{* *}$ & $.399^{* *}$ \\
\hline
\end{tabular}

Note. Importance of level of connection: ${ }^{*}-.99$ 
When we compared results by gender (the sample group comprised 96 people, with 31 men and 65 women), we noted considerable differences in the MK scale (using the Mann-Whitney $U$ test): the men rated the general functioning level of their own cognitive psychic processes higher; and we noted as well their greater ease in acquiring new knowledge ( $p \leq .001)$; no significant differences were discovered on the MA scale. Comparing sample groups by age showed that readings on both questionnaire scales were higher for the young lecturers than for the students $(p \leq .02)$. The reliability coefficient was defined by the Spearman-Brown prediction formula; test-retest reliability was calculated according to Pearson's correlation coefficient (Table 3).

At the third stage of working out the questionnaire, approximate norms were defined. (The sample group consisted of 179 people, 56 lecturers and 123 students.)

We analyzed the connection between the PPT level of the university lecturers and their metacognitive characteristics. The correlational connection between PPT level and the MA scale, defined with Spearman's rank correlation coefficient $(r=.316, p \leq .015)$, means that the higher the lecturers valued their skills in managing their own cognitive processes, their efficiency in planning their own cognitive activity, and their use of various approaches to structuring information, the higher was their diagnosed PPT level. In addition, the PPT level definitely differed between the lecturers with extreme (high and low) MA scale readings (MannWhitney $\mathrm{U}=18.50, p \leq .011)$. This result proves the hypothesis that the PPT level of university lecturers is a characteristic related to their level of metacognitive activity.

We also established that the higher-metacognitive teachers (by the MA scale) had a higher need for achievement $(\mathrm{U}=22.00, p \leq .05)$ and acknowledged a greater number of factors that stimulated their learning and development $(\mathrm{U}=22.00$, $p=.05)$ than did teachers with lower scores. The sphere of interpersonal communication of the higher-metacognitive teachers was characterized by a smaller inclination toward autocratic, dictatorial, and pedantic behavior (Interpersonal Diagnosis of Personality by Leary, Leforge, and Sathek, AP scale, $U=15.5, p \leq .015$ ) as well as by an inclination toward cooperation, but without too much friendliness and searching for social approval (LM scale, $\mathrm{U}=24.00, p \leq .05$ ).

\section{Discussion}

The data obtained at the first stage of research confirmed some of the ideas and practical results of other scientists. Thus, Russian psychologists have often stated that, for evaluation of individual intellectual abilities, the important factor is not so much the characteristics of "analytical" (cognitive) processes but rather the characteristics of "integral psychic processes" (goal-making, planning, forecasting, decision-making); these processes, in turn, provide for organization and regulation of intellectual activity, as they are formed on the basis of the synthesis and coordination of analytical processes (Shadrikov, 1996). The role of metacognitions as a special level of constructive activity aimed at managing thinking and choice is mostly manifested in unfolding integral psychic processes (Kornilova, 2009). 
We chose forecasting as one of these integral processes. The formation of suprasituational thinking and, in particular, its component - forecasting - was realized within the framework of the forecasting and planning prospects of one's own professional development and of the specific strategies and tactics for structuring the performed activity - namely, solving specific communication problems arising in the course of the educational process among students, parents, colleagues, and managers. Theoretical analyses of the works of both Russian scientists (A.A. Bodalyov, A.V. Brushlinsky, N. V. Kuzmina, A.K. Markova, L.M. Mitina, Ye.K. Osipova, L.A. Regush, M.I. Volovikova, V.A. Yakunin) and foreign scientists (G. Mohlenkam, I. Zimmer), reported in our previous publication (Serafimovich, 2013), proved that forecasting is one of the reasons for efficient resulting activity. Our data confirm these results and also allow us to conclude that this efficiency can be found not only in outer activity performance but in the quality changes in professional thinking level.

The obtained data concerning the development and transformation of situational structural-level characteristics into supra-situational ones through gaining knowledge and acquiring competence while studying at a university correlate with the data of Perkins \& Salomon (1987): specifically, the knowledge base in which a person is competent allows for the development of metacognitive abilities (in our case, the metacognitive orientation of supra-situational thinking) with metacognitive control over activity (and, in our case, over the process of problem solution) and provides an opportunity for success. The important role of metacognitive processes in obtaining high activity results has been described in the works of J. Borkowski, M. Carr, and M. Pressley; T.O. Nelson and L. Narens; N.A. Menchinskaya; M.A. Kholodnaya; A.V. Karpov; and others. Our research also confirmed the role of metacognitive processes in the success of educational activity. Further professional development and formation of the characteristics of professional thinking are also closely connected with metacognitive activity. One can suppose that such a connection is preconditioned by the need-motivation sphere of teachers with high PPT levels. At the same time, metacognitive control also includes the sphere of interpersonal relations, which provides for the possibility of a supra-situational resolution of pedagogical problem situations.

\section{Conclusion}

First, based on our analysis and generalization of the acquired empirical data we can state that the role of metacognitive components (metacognitive knowledge and metacognitive activity) in the PPT of university lecturers has been discovered. The notion of the dynamics of the level of organization of PPT has been expanded: one of the possible mechanisms of transfer to the supra-situational level of PPT has been revealed.

Second, components and strategies of metacognition, incorporated into the PPT process, define (through conscious and unconscious regulation) the efficiency of discovering and solving problems in a situation of interpersonal interaction. A high level of metacognitive activity is one of the conditions for the realization of a professional's supra-situational-type thinking; besides, metacognitive activity is an invariant feature regardless of the possession or the lack of a basic professional 
education. Expansion of the number of metacognitive strategies used by lecturers is a necessary but insufficient condition for their PPT growth.

Third, situational and supra-situational types of PPT are characterized by various properties of forecasting activities, which determine their differentiation and hierarchization. The metacognitive properties of supra-situational thinking (involvement in the situation, constructive encroachment beyond the limits of the situation to be resolved, transformative thinking aimed at oneself as the basic subject of cognition, and the resolution of the problem situation) are realized when all forecasting properties are present (analyticity, depth, awareness, flexibility, prospectness, and validity) and highly integrated. The formation of supra-situational thinking and, in particular, of forecasting as its component (in a narrow and a broad context), is closely connected with both envisaging prospects, including one's own professional development, and being aware of and acquiring specific strategies and tactics for solving communication problems arising from cooperation with various subjects in the learning process (students, parents, colleagues, and managers).

Fourth, the metacognitive orientation of forecasting stimulates formation and development of its various types (proactive, retroactive, and interactive) and determines differences in the structure of the psychological system of activity. These differences are most vividly exhibited in goals, programs of activities, and decisionmaking and are manifested in the motivational component and the informational basis of activity and of the professionally important qualities of the subjects.

\section{Acknowledgments}

Our research was carried out with the financial support of the Russian Foundation for Humanities, project No. 15-06-10823a.

\section{References}

Borkowski, J. G., \& Muthukrishna, N. (1992). Moving metacognition into the classroom: "Working models" and effective teaching strategy. In M. Pressley, K. R. Harris, \& J. T. Guthrie (Eds.), Promoting academic literacy: Cognitive research and instructional innovation (pp. 477-501). Orlando, FL: Academic Press.

Briñol, P., Petty, R.E., \& Barden, J. (2007). Happiness versus sadness as determinants of thought confidence in persuasion: A self-validation analysis. Journal of Personality and Social Psychology, 93, 711-727.

Brushlinsky, A. V. (1977). Psihologicheskij analiz myshlenija kak prognozirovanija [Psychological analysis of thinking as forecasting]. Moscow: Institute of Psychology of RAN.

Cacioppo, J. T., Petty, R. E., \& Kao, C. F. (1984). The efficient assessment of need for cognition. Journal of Personality Assessment, 48, 306-307. doi: 10.1207/s15327752jpa4803_13

Chernokova, T. E. (2011). Metakognitivnaja psihologija: problema predmeta issledovanija [Metacognitive psychology: The problem of the subject of research]. Vestnik primorskogo universiteta: gumanitarniye i sotsialniye nauki [Bulletin of Northern (Arctic) Federal University: Humanities and Social Studies], 3, 153-158.

Clause, C. S., Delbridge, K., Schmitt, N., Chan, D., \& Jennings, D. (2001). Test preparation activities and employment test performance. Human Performance, 14(2), 149-167. doi: 10.1207/ S15327043HUP1402_02 
Flavell, J. H., Miller, P. H., \& Miller, S. A. (2002). Cognitive development (4th ed.). Englewood Cliffs, NJ: Prentice-Hall Publishing.

Fox, E., \& Riconscente, M. (2008). Metacognition and self-regulation in James, Piaget, and Vygotsky. Educational Psychology Review, 20, 373-389. doi: 10.1007/s10648-008-9079-2

Gigerenzer, G., \& Gaissmaier, W. (2011). Heuristic decision making. Annual Review of Psychology, 62, 451-482. doi: 10.1146/annurev-psych-120709-145346

Gonobolin, F. M. (1951). Ocherki psihologii truda uchitelja [Essay on teachers' professional psychology]. Moscow: APN RSFSR.

Karpov, A. V., \& Skityayeva, I. M. (Eds.). (2005). Psihologija metakognitivnyh processov lichnosti [The psychology of metacognitive personality processes]. Moscow: Institute of Psychology RAN.

Kashapov, M. M. (2000). Psihologija professionalnogo pedagogicheskogo myshlenija [The psychology of pedagogical thinking]. St. Petersburg: Aleteya.

Kholodnaya, M. A. (2002). Kognitivnye stili. O prirode individualnogo uma [Cognitive styles. On the nature of the individual mind]. St. Petersburg: Piter.

Kluwe, R. H. (1982). Cognitive knowledge and executive control: Metacognition. In D. R. Griffin (Ed.)., Animal mind - human mind (pp. 201-224). New York: Springer-Verlag.

Kornilova, T. V. (2009). Neopredelennost, vybor i intellektualno-lichnostnyj potencial cheloveka [Uncertainty, choice and personality-intellectual potential of a man (an elaboration of semantic thinking theory)]. Metodologiya $i$ istoriya psikhologii [Methodology and History of Psychology, 4(4), 47-59.

Kramarski, B. (2008). Self-regulation in mathematical e-learning: Effects of metacognitive feedback on transfer tasks and self-efficacy. In A. R. Lipshitz \& S. P. Parsons (Eds.), E-learning: 21st century issues and challenges (pp. 83-96). New York: Nova Science.

Kudryavtsev, V. T. (1997). Vybor i nadsituativnost $\mathrm{v}$ tvorcheskom processe: opyt logikopsihologicheskogo analiza problem [Choice and supra-situativity in the creative process: An attempt at the logical-psychological analysis of problems]. Psikhologichesky Zhurnal [Psychological Journal], 1, 16-31.

Kulyutkin, Yu. N. (1986). Tvorcheskoe myshlenie v professionalnoj dejatelnosti pedagoga [Creative thinking in teachers' professional activities]. Voprosy Psikhologii [Issues in Psychology], 2, 21-30.

Kuzmina, N. F. (1961). Formirovanie pedagogicheskih sposobnostej [Formation of pedagogical abilities]. Leningrad, Russia: Leningrad State University.

Litvinov, A. V., \& Ivolina, T. V. (2014). Metakognicija: Ponjatie, struktura, svjaz s intellektualnymi kognitivnymi sposobnostjami (po materialam zarubezhnyh issledovanij) [Metacognition: Notion, structure, relation to intellectual cognitive abilities (based on foreign research materials)], 59-60. Retrieved from http://psychlib.ru/mgppu/periodica/SZP032013/SZP-0591. htm

Markova, A. K. (1993). Psihologija truda uchitelja [The psychology of teachers' work]. Moscow: Prosveshcheniye.

Matyushkin, A. M. (1972). Problemnye situacii v myshlenii i obuchenii [Problem situations in thinking and learning]. Moscow: Pedagogika.

Mazilov, V. A. (1998). Psihologija prakticheskogo pedagogicheskogo myshlenija kak romanticheskaja nauka [The psychology of practical pedagogical thinking as a practical science]. In Psihologija pedagogicheskogo myshlenija: teorija i praktika [Collected articles. The psychology of pedagogical thinking: Theory and practice] (pp. 66-81). Moscow: Institute of Psychology RAN.

Mitina, L. M. (1998). Psihologija professionalnogo razvitija uchitelja [The psychology of teachers' professional development]. Moscow: Flinta. 
Osipova, Ye. K. (1987). Struktura pedagogicheskogo myshlenija uchitelja [Structure of teachers' pedagogical thinking]. Voprosy psikhologii [Issues in Psychology], 5, 144-146.

Perkins, R., \& Salomon, B. (1987). Metacognitive and control strategies revised. Social Psychology Journal, 3, 13-18.

Petty, R. E., Tormala, Z. L., \& Rucker, D. D. (2004). Resisting persuasion by counter arguing: An attitude strength perspective. In J. T. Jost, M. R. Banaji, \& D. A. Prentice (Eds.), Perspectivism in social psychology: The yin and yang of scientific progress (pp. 37-51). Washington, DC: American Psychological Association.

Pintrich, R. R., \& DeGroot, E. V. (1990). Motivational and self-regulated learning components of classroom academic performance. Journal of Educational Psychology, 82, 33-40. doi: 10.1037/0022-0663.82.1.33

Poshekhonova, Yu. V. (2012). Metakognitivnye processy i tvorcheskij podhod k resheniju pedagogicheskih problemnyh situacij [Metacognitive processes and the creative approach to the resolution of pedagogical problem situations]. In M. M. Kashapov \& Yu. V. Poshekhonova (Eds.), Tvorcheskaja dejatelnost professionala $v$ kontekste kognitivnogo i metakognitivnogo podhodov [Creative activity of professionals within the framework of cognitive and metacognitive approaches]. (pp. 122-154). Yaroslavl, Russia: Yaroslavl State University.

Povaryonkov, Yu. P. (1998). Formirovanie professionalnogo intellekta v processe obuchenija $\mathrm{v}$ pedagogicheskom universitete [The formation of professional intellect in the course of study at a teachers' training university]. In M.M. Kashapov (Ed.), Psihologija pedagogicheskogo myshlenija: teorija i praktika [The psychology of pedagogical thinking: Theory and practice] (pp. 111-122). Moscow: Institute of Psychology RAN.

Prytula, M. P. (2012). Teacher metacognition within the professional learning community. International Education Studies, 5(4), 112-121. doi: 10.5539/ies.v5n4p112

Putlyaeva, L. V. (1986). Ponimanie i poznavatelnaja dejatelnost [Comprehension and cognitive activity]. In V. M. Kuznecov, L. V. Putljaeva (Eds.), Aktivnost lichnosti v obuchenii (psihologo-pedagogicheskij aspekt) [Personal activity in learning (psychological-pedagogical aspect)] (pp. 48-60). Moscow: NII PVSh.

Regush, L. A. (1985). Razvitie prognozirovanija kak poznavatel'noj sposobnosti lichnosti [The development of forecasting as a personal cognitive ability]. (Unpublished doctoral dissertation). Leningrad State University, Leningrad, Russia.

Rubinstein, S. L. (2000). Osnovy obshhej psihologii [Basic general psychology]. St. Petersburg: Piter.

Serafimovich, I. V. (2002). Osobennosti prognozirovanija v strukture professionalnogo pedagogicheskogo myshlenija [Forecasting peculiarities within the framework of professional pedagogical thinking]. (Unpublished master's thesis). Yaroslavl State University, Yaroslavl, Russia.

Serafimovich, I.V. (2013). Vlijanie prognosticheskoj metakognicii na konfliktnuju kompetentnost" v professijah tipa «chelovek - chelovek» [Impact of forecasting metacognition on conflict competence in "man - man" type professions]. Vestnik Chelyabinskogo universiteta [Bulletin of Chelyabinsk State University], 34(325), 6-14.

Shadrikov, V. D. (1996). Psihologija dejatelnosti i sposobnosti cheloveka [The psychology of human activities and abilities]. Moscow: Logos.

Shebetenko, S. A. (2011). Psihometrika russkoj versii Shkaly potrebnosti v poznanii [Psychometrics of the Russian version of the need for cognition scale]. Vestnik Permskogo universiteta [Perm University Bulletin], 2(6), 87-100.

Sperling, R. A., Howard, B. C., Miller, L. A., \& Murphy C. (2002). Measures of children's knowledge and regulation of cognition. Contemporary Educational Psychology, 27, 51-79. doi: 10.1006/ceps.2001.1091 
Sternberg, R. (1998). Metacognition, abilities, and developing expertise: What makes an expert student? Instructional Science, 26(1-2), 127-140.

Sukhobskaya, G. S. (1975). Motivacionno-cennostnye aspekty poznavatel'noj dejatel'nosti vzroslogo cheloveka [The value-motivation aspect of adult cognitive activity] (Unpublished doctoral dissertation). Leningrad, Russia: Leningrad State University.

Tormala, Z.L., \& DeSensi, V.L. (2008). The perceived informational basis of attitudes: Implications for subjective ambivalence. Personality and Social Psychology Bulletin, 34, 275-287.

Whitebread, D. (2014). The importance of self-regulation for learning from birth. In H. Moylett (Ed.). Characteristics of effective learning: Helping young children become learners for life (pp. 15-35). Open University Press.

Znakov, V. V. (2012). Integrativnyj fenomen jekzistencialnogo opyta kak problema psihologii chelovecheskogo bytija [The integrative phenomenon of existential experience as a problem of human entity psychology]. In M. M. Kashapov \& Yu. V. Poshekhonova (Eds.), Tvorcheskaja dejatelnost professionala $v$ kontekste kognitivnogo i metakognitivnogo podhodov [Creative activity of professionals within the framework of cognitive and metacognitive approaches]. (pp. 10-34). Yaroslavl, Russia: Yaroslavl State University.

Original manuscript received November 19, 2015

Revised manuscript accepted May 18, 2016 First published online March 31, 2017 